\title{
Han's (???) Novel ????? (The Sing-Song Girls of Shanghai) and Urbanity in Late Qing Shanghai
}

\author{
Xiaojue Wang \\ University of Pennsylvania
}

Follow this and additional works at: https://docs.lib.purdue.edu/clcweb

Part of the Chinese Studies Commons, Comparative Literature Commons, Feminist, Gender, and Sexuality Studies Commons, and the Modern Literature Commons

Dedicated to the dissemination of scholarly and professional information, Purdue University Press selects, develops, and distributes quality resources in several key subject areas for which its parent university is famous, including business, technology, health, veterinary medicine, and other selected disciplines in the humanities and sciences.

CLCWeb: Comparative Literature and Culture, the peer-reviewed, full-text, and open-access learned journal in the humanities and social sciences, publishes new scholarship following tenets of the discipline of comparative literature and the field of cultural studies designated as "comparative cultural studies." Publications in the journal are indexed in the Annual Bibliography of English Language and Literature (Chadwyck-Healey), the Arts and Humanities Citation Index (Thomson Reuters ISI), the Humanities Index (Wilson), Humanities International Complete (EBSCO), the International Bibliography of the Modern Language Association of America, and Scopus (Elsevier). The journal is affiliated with the Purdue University Press monograph series of Books in Comparative Cultural Studies. Contact: <clcweb@purdue.edu>

\section{Recommended Citation}

Wang, Xiaojue. "Han's (???) Novel ????? (The Sing-Song Girls of Shanghai) and Urbanity in Late Qing Shanghai." CLCWeb: Comparative Literature and Culture 17.1 (2015): <https://doi.org/10.7771/1481-4374.2585>

This text has been double-blind peer reviewed by $2+1$ experts in the field.

The above text, published by Purdue University Press @Purdue University, has been downloaded 283 times as of $11 /$ $07 / 19$.

This document has been made available through Purdue e-Pubs, a service of the Purdue University Libraries. Please contact epubs@purdue.edu for additional information.

This is an Open Access journal. This means that it uses a funding model that does not charge readers or their institutions for access. Readers may freely read, download, copy, distribute, print, search, or link to the full texts of articles. This journal is covered under the CC BY-NC-ND license. 


\title{
PURDUE
}

UNIVERSITY PRESS <http://www.thepress. purdue.edu>

\section{CLCWeb: Comparative Literature and Culture}

ISSN 1481-4374 <http://docs.lib.purdue.edu/clcweb> Purdue University Press @Purdue University

CLCWeb: Comparative Literature and Culture, the peer-reviewed, full-text, and open-access learned journal in the humanities and social sciences, publishes new scholarship following tenets of the discipline of comparative literature and the field of cultural studies designated as "comparative cultural studies." In addition to the publication of articles, the journal publishes review articles of scholarly books and publishes research material in its Library Series. Publications in the journal are indexed in the Annual Bibliography of English Language and Literature (Chadwyck-Healey), the Arts and Humanities Citation Index (Thomson Reuters ISI), the Humanities Index (Wilson), Humanities International Complete (EBSCO), the International Bibliography of the Modern Language Association of America, and Scopus (Elsevier). The journal is affiliated with the Purdue University Press monograph series of Books in Comparative Cultural Studies. Contact: <clcweb@purdue.edu>

\author{
Volume 17 Issue 1 (March 2015) Article 9 \\ Xiaojue Wang, \\ "Han's (韓邦慶) Novel 海上花列專 (The Sing-Song Girls of Shanghai) \\ and Urbanity in Late Qing Shanghai" \\ <http://docs.lib.purdue.edu/clcweb/vol17/iss1/9> \\ Contents of CLCWeb: Comparative Literature and Culture 17.1 (2015) \\ Thematic Issue The Study of Chinese Literature in the Anglophone World. Ed. Shunqing Cao \\ <http://docs.lib.purdue.edu/clcweb/vol17/iss1/>
}

Abstract: In her article "Han's (韓邦慶) Novel 海上花列傳(The Sing-Song Girls of Shanghai) and Urbanity in Late Qing Shanghai" Xiaojue Wang discusses the relationship between the urban milieu in the foreign concessions of Shanghai and the late Qing courtesan culture through a critical reading of Bangqing Han's (韓邦慶 1856-1894) novel The Sing-Song Girls of Shanghai. Wang argues that Han's novel is a significant departure from traditional vernacular fiction in three aspects: 1) its illustration of the connection between courtesan culture and the rising modern city, 2) its portrayal of emergent female subjectivity and female space in the late Qing, and 3) the significance of its narrative discrepancy. The novel is composed of two parts: one situated in Shanghai's concessions and the other in Yili Yuan, an imaginary classical Chinese garden. Wang discusses how in the novel narrative disparity is a consequence of the Han's efforts to reshuffle ambivalent cultural and ethical values in a transitional age in China. 
Xiaojue Wang, "Han's (韓邦慶) Novel 海上花列傳 (The Sing-Song Girls of Shanghai) and Urbanity in Late Qing Shanghai" page 2 of 8 CLCWeb: Comparative Literature and Culture 17.1 (2015): <http://docs.lib.purdue.edu/clcweb/vol17/iss1/9>

Thematic Issue The Study of Chinese Literature in the Anglophone World. Ed. Shunqing Cao

\section{Xiaojue WANG}

\section{Han's (韓邦慶) Novel 海上花列傳 (The Sing-Song Girls of Shanghai)} and Urbanity in Late Qing Shanghai

In the study at hand, I analyze Bangqing Han's (韓邦慶 1856-1894) novel 海上花列傳 (The Sing-Song Girls of Shanghai. Trans. Eileen Chang) with regard to its relevance in English-language scholarship about urbanity in nineteenth-century Chinese literature, an as-of-yet less studied area. The Sing-Song Girls of Shanghai is one of the first full-length novels dedicated to the description of the courtesan life in Shanghai of the last decades of the nineteenth century. The first twenty-eight chapters were serialized in 1892 in the biweekly 海上奇書 (The Wonderbook of Shanghai), the first literary magazine that appeared in late Qing dynasty and that was founded by Han. The complete novel with sixty-four chapters was published in 1894.

If you want to find your husband, you should look for him in your own house. Did you ever entrust him to our care, so as to give you the right to come and look for him here? This sing-song house has never sent someone to your residence to invite our client over, yet you're here now in search of your husband; isn't that a joke? We're a house open for business; anybody who walks in is a client. What do we care whose husband he is? ... Let me put it to you straight: Second Young Master may be your husband at home, but when he is here, he's our client. If you're smart, you should keep a close eye on your husband. Why did you let him out to have fun in sing-song houses? When he's already in a sing-song house, d'you think you can drag him out? Go and ask around; is there such a rule in these foreign settlements? (The Sing-Song 187-88)

With these words Xiaxian Wei, one of the top-ranking changsan 長三 courtesans in the novel fights the wife of her patron, Jicun Yao who comes to Wei's courtesan house to search for her husband, Yao, and is rendered speechless by Wei's argument. Changsan shuyu 長三害寓 is a first-class courtesan house in the late Qing Shanghai pleasure quarter. In The Sing-Song Girls, although Han gives a panoramic depiction of prostitution in Shanghai over the last decades of the nineteenth century with prostitutes ranging from changsan to 么二 (yao'er, courtesan of lower rank) and 人家人 (renjia ren) to the lowest category, 野雞 (yeji, streetwalkers), he focuses on changsan courtesans (for a study of the hierarchy of prostitution in late Qing Shanghai, see Hershatter; Yeh). Shi Hu quotes the whole passage in his preface to the 1926 Yadong edition of The Sing-Song Girls to give an example of how the Wu dialect captures the mood, tone, and personality of a character. In the 1926 preface, which was later included in the Guangya edition of 1984, Hu confirms the authorship of the novel and conducts a biographical research on Han. Hu considers The Sing-Song Girls "the first literary masterpiece in Wu dialect" in the history of Chinese vernacular fiction (22), and Wei's words serve as a case in point to attest to the novel's linguistic distinction. The same passage was quoted by Eileen Chang in the preface of her Mandarin translation of The Sing-Song Girls in 1981 (640).

In addition to the uniqueness of the regional tongue, however, there is more that is unprecedented in Wei's remarks. First, Wei protects herself and the courtesan house by invoking 夷場規矩 (yichang guiju, regulations of the foreign concessions of Shanghai). This indicates the crucial linkage between the special political setting of the Shanghai Concession and the courtesan house as a legalized social institution protected by the Municipal Council. As the boom of courtesan culture in the foreign concessions of Shanghai occurred with the rise of the first modern metropolis in China, the modern urban configurations also considerably transformed the late Qing courtesan culture, the very site of urbanity. Second, in Wei's argument, the courtesan house 堂子 (tangzi), regarded through the ages as a debased space at the margin of the orthodox socioethical order, stands as an autonomous counterpart to the familial sphere 府上 (fushang) (for a study of how the Confucian dictum regulated a woman's life in the late Ming and early Qing period, see Ko). With its treaty rights of extraterritoriality, modern urban facilities, Western-style municipal management, and relatively free economic and political status, the Shanghai Concession constitutes a new territory of "Otherness" as compared to the traditional Chinese society. This "extraterritory," which is called 夷場 (yichang 租界, district of barbarians) and is separated from old Shanghai City 華界 (huajie, district of the Chinese) by the city wall, also opens up a new space for the courtesan house, which is always already out of bounds, excluded from the orthodox social hierarchy. 
Xiaojue Wang, "Han's (韓邦慶) Novel 海上花列傳 (The Sing-Song Girls of Shanghai) and Urbanity in Late Qing Shanghai" page 3 of 8 CLCWeb: Comparative Literature and Culture 17.1 (2015): <http://docs.lib.purdue.edu/clcweb/vol17/iss1/9>

Thematic Issue The Study of Chinese Literature in the Anglophone World. Ed. Shunqing Cao

My questions are as to how does the rising commercial urban milieu in the foreign concessions of Shanghai, where the top courtesan houses are situated, transform the late Qing courtesan culture? Accordingly, how is the courtesan persona in late Qing concessions defined and a new subjectivity and space of these femmes fatale-s shaped? Further, I discuss distinctive narrative structure of Sing-Song Girls. Ever since the rebirth of the novel during the May Fourth period, the part set in Yili Yuan, a private garden of the mansion of an elderly traditional style literatus, Yunsou Qi, has been regarded as in dissonance with the rest of the novel. In this imaginary, walled classical space, the clientele changes from concession merchants into traditional literati and consequently the disposition of the courtesan culture differs significantly from that in the courtesan district of the city. Although The Sing-Song Girls was not a popular novel in the late Qing, it received much attention among May Fourth intellectuals including Lu Xun, Hu, Liu Fu, and later by Eileen Chang. Chang completed a Mandarin translation of the novel in 1981 and later translated the entire novel into English. The Yili Yuan part was condemned by May Fourth critics for breaking the literary excellence of the novel. Liu, for example, rejected this part and regarded it as "an intolerable flaw of the novel" (600; unless indicated otherwise, all translations are mine). Chang, in her Mandarin rendition, truncates four chapters from Han's original novel, all of which are from the Yili Yuan part. Whereas it was critiqued by May Fourth intellectuals, this narrative discrepancy barely received any notice or discussions in later scholarship on The Sing-Song Girls.

How to cope with the discrepancy in the narrative form? The apparent disparity between the concession part and the Yili Yuan part of the novel bespeaks the imbrication of the traditional and the emergent modern aspects of life in late Qing Shanghai and is a necessary consequence of the author's efforts to reshuffle ambivalent cultural and ethical values in this transitional moment. Eileen Chang speaks highly of the open ending of The Sing-Song Girls and regards it as attesting to the modern quality of this late Qing novel ("Postscript" 639). This article considers the novel a significant departure from traditional vernacular fiction by exploring three aspects: its illustration of the connection between the courtesan culture and the rising modern city, its portrayal of the emergent female subjectivity and female space in late Qing courtesan life, and the significance of its narrative discrepancy.

Late Qing Shanghai witnessed not only a revival of high courtesan culture but also a surge of literature on courtesan life, which included a wide range of genres, such as 筆記 (biji, random notes), diaries, travelogues, 竹枝詞 (zhuzhi ci, bamboo twig ballads), and novels (see Henriot; Zamperini; Yeh). Han's The Sing-Song Girls stands out in that the city figures prominently in it. In discussing the temporal and spatial constellation of The Sing-Song Girls, Yingjin Zhang observes that urban experiences are an integral part of the sexual adventures and "sensual experiences at the pleasure quarters in Shanghai" (121). In his examination of late Qing courtesan novels as a key form of the "depravity genre," David Der-wei Wang points to the importance of Shanghai as a unique geographical locale in The Sing-Song Girls and suggests that this novel "anticipates the literary style and posture later called the 'Shanghai style,' or 'haipai'" (90). To investigate the changing relationship between customers and prostitutes and the changing courtesan practice manifested in The Sing-Song Girls, Keith McMahon contextualizes the novel in the tradition of Ming and Qing dynasty courtesan fiction and maintains that its "departures from its literary past, in fact, gain much of their weight from the singular nature of the city of Shanghai" (6).

In the Qing dynasty, official prostitution was prohibited and by 1673 the Qing court ended the long tradition of maintaining official prostitutes in the imperial capital and the provinces (see, e.g., Xue). Ironically, it was the imperial hegemony in the Shanghai Concession that reinstated the legal position of the courtesan house and ushered in the golden age of high courtesan culture in late Qing. The rise of the courtesan culture in Shanghai international settlements marked an emergent new urban culture sustained by economic prosperity. The reference map on the inside front cover of the Mandarin version of The Sing-Song Girls charts the topography of Shanghai over the last decades of the nineteenth century: the district of the Chinese (South City) versus the Foreign Concession (North City). This Chinese/foreign constellation is already laid bare in the opening scene of the novel. When the narrator wakes from a dream in which he is walking on a sea completely covered with flowers, he finds himself on the stone bridge that separates the Chinese district and the foreign settlements. At this threshold between dreamland and the reality, the traditional and the modern, the narrator bumps into a young man named Puzhai Zhao, one of the main characters in the novel, and the story begins. 
Xiaojue Wang, "Han's (韓邦慶) Novel 海上花列傳 (The Sing-Song Girls of Shanghai) and Urbanity in Late Qing Shanghai" page 4 of 8 CLCWeb: Comparative Literature and Culture 17.1 (2015): <http://docs.lib.purdue.edu/clcweb/vol17/iss1/9>

Thematic Issue The Study of Chinese Literature in the Anglophone World. Ed. Shunqing Cao

According to the treaty rights of extraterritoriality, the Municipal Council of the Shanghai Concession enjoyed legislative and administrative powers and regulated taxation, finance, and the police force. The economic boom of the Concession did not start until the rebel troops of the Kingdom of Heavenly Peace (the Taipings 1850-1864) and the Small Swords Society (Xiaodao hui 1853) drove massive populations of Chinese refugees from Shanghai's Chinese City and neighboring provinces into the foreign settlements. The status of 華洋分處 (huayang fengchu, separation of the Chinese and foreigners) thus changed: "From the 1850s on, each new social disturbance in the interior sent tens of thousands of Chinese refugees to Shanghai, seeking protection under the English and French flags" (Wakeman and Yeh 1). These immigrants brought wealth and labor into the Concession. With the development of a Westernized urban culture with totally new lifestyles, a space of "Otherness" emerged outside the walls of the old Chinese city of Shanghai.

The following data provide a rough urban physiognomy of the Shanghai Concession, which makes up the texture of life in The Sing-Song Girls: in 1864 the Shanghai Gas Company was founded by British traders and all street lamps were changed into gas lamps; in 1880 The Shanghai Waterworks was established and two years later the Concession started to use running water; and in 1882 the Shanghai Electricity Company was founded by British traders and electric lamps appeared in the Concession the same year (see Ma). With the rise of modernity in the city, the courtesan house started to thrive as a licensed entertainment business of a type and dimension unavailable anywhere else in China, which in turn promoted the urban development of the concessions. Theaters, singing halls, storytelling houses, teahouses, and Western-style restaurants blossomed along the city's most glamorous commercial street, where the top courtesan houses were located. But how was the courtesan culture realigned with the new urban environment? The Shanghai courtesans were situated on the cutting edge of trends experimenting with Western fashions. They were the earliest beneficiaries of gas lamps and running water as well as the earliest regular customers of Western stores and restaurants. They were the first women whose photographs were exhibited in display windows of photo studios and circulated via pamphlets and newspapers. In chapter 21, Sanjie Zhu brags about being one of the famous "seven sisters," seven sorority courtesans in Shanghai, whose photo was once displayed in the window of the largest commercial photo studio (164). In such a transitional period, to be modern meant not only to be à la mode, but also to have the potential to transgress the boundaries of tradition. Western-style urban culture not only pervaded these high-profile courtesans' private living space and changed the texture of their daily life, but also enlarged their venues of entertainment and enhanced their public exposure. The carriage parades of courtesans and their clients through the commercial district offered the most striking example of public visibility.

While the adoption of the Western seven-day-week structure and the introduction of gas and electric lamps extended the temporal scope of courtesan life, the emergence of a new transportation system expanded the spatial parameters of the city and enhanced the accessibility of the public parks located in the suburbs. In late nineteenth-century Paris, it was haute couture to ride a horse-drawn carriage down the city boulevards. In Baudelaire's Paris, five hundred carriages were circulated around the city for the Parisian haute bourgeoisie (see Benjamin). Alexandre Dumas published in $1856 \mathrm{La}$ Dame aux Camélias and it was translated by Shu Lin and Shouchang Wang in 1899 and exerted tremendous impact on late Qing and early Republican Chinese fiction. Similar to Dumas's Paris, in Shanghai concessions it was also high fashion to ride with a courtesan in a horse-drawn carriage: the most popular route for carriage rides was from the main commercial streets through the Bund to the Jing'an Temple and to Zhang Yuan (see chapters 6, 7, 12). In The Sing-Song Girls, a carriage ride is not only an important part of a courtesan's everyday life, but also a key narrative device. In late Qing Shanghai, Western-style urban culture not only penetrates into the private living space and the everyday life of courtesans, but also enlarges considerably their venue and enables them to expand their activities into the public realm. Here the carriage parade of courtesans and patrons through the commercial avenues to Zhang Yuan, the first public garden in the Shanghai concessions opened to Chinese people, offers a salient example of the public visibility.

Among the first public spaces ever to emerge in China, Zhang Yuan is no doubt of great significance in late Qing literary imagination. Opened to the public in 1885, it was a Western-style garden including a theater, a photo studio, a Western-style Arcadia, and a zoo. In many fictional texts of late Qing, such as Qichao Liang's 新中國未來記 (The Future of New China, 1902) and Boyuan Li's 文明小史 
Xiaojue Wang, "Han's (韓邦慶) Novel 海上花列傳 (The Sing-Song Girls of Shanghai) and Urbanity in Late Qing Shanghai" page 5 of 8 CLCWeb: Comparative Literature and Culture 17.1 (2015): <http://docs.lib.purdue.edu/clcweb/vol17/iss1/9>

Thematic Issue The Study of Chinese Literature in the Anglophone World. Ed. Shunqing Cao

(Modern Times, 1906), Zhang Yuan is depicted as the very site for public affairs where reformers or revolutionaries meet and give speeches. As urbanism in the Shanghai Concession rewrote the material and cultural dispositions of courtesan life, courtesan culture became a new social space for highranking sing-song girls. How do we define this new social space and where does it stand vis-à-vis the traditional familial system? Does public visibility of the Shanghai courtesans in the Concession over the last decades of the nineteenth century suggest a rewriting of womanhood? Whereas courtesan culture makes a glorious spectacle in the modern façade of public life in the Concession, the novel presents courtesan houses characterized by an ordinary familial style. Critics and scholars duly noted the quotidian, prosaic feature of the courtesan life depicted in this novel. Chang, for instance, observes that there is no "sensuous quality" in this fiction devoted to a sensuous topic, that is, the pleasure quarters in Shanghai ("Yi Hushi" 154). Whereas the late Ming courtesan culture is celebrated for images of stylized talented courtesans situated in a realm beyond vulgar sensuality, its late Qing counterpart featured a plain, domestic atmosphere with a group of courtesan-housewives (see Carlitz). Whereas the late Qing courtesan culture is inlaid as a glorious spectacle in the modern façade of the public life in the Shanghai concessions, these women maintain a traditional domestic interior within the courtesan house and play the role of traditional wives.

Traditional familial ties, which are of course absent in pleasure houses, are imitated and emphasized in a remarkable way. For example, courtesans address each other sisters and in effect receive names suggestive of a sibling relationship. In the third chapter, when the courtesan house run by Lan Zhou buys a new girl, she is named Shuangyu Zhou (a pair of jade) after the leading courtesan in the "family." What defines the relationship between customs and courtesans is no more 才子佳人 (caizi jiaren, scholar-beauty) romance prevalent in Ming and Qing literary tradition. Even in early Qing courtesan novels the romantic relationship between clients and courtesans is constructed on the scholarbeauty model (see Li; Mann). Many handbooks and guides for the courtesan world in circulation flourished in Shanghai since the 1870s, delineated the complicated rules and rituals in the courtesan house and illustrated proper behavior for a client (see, e.g., Yeh). The clients and courtesans in The SingSong Girls maintain a relationship similar to that of husbands and wives in everyday life and it is not uncommon for a client to sustain a liaison with the same courtesan for four or five years. However, the sing-song girls' behavior and practices of "family life" does not suggest that Shanghai courtesans opened up new terrain and acquired a modern persona to subvert or at least compete with the traditional familial order. Rather, what they did was to partake in a complicated process of compromise and negotiations between contrary forces. Often, the emergence of possibilities for courtesans to inhabit new social and family positions only exposed the strict boundary between a conventional family space and its imitator in the pleasure quarter. This demarcation was reinforced not only by defenders of traditional social hierarchy but also, more intriguingly, by courtesans themselves.

To marry a client as his legal wife would be the ideal for any courtesan. A more practical and seemingly easy solution was to marry a client as his concubine, thereby entering the family system. This is referred to as 從良 (congliang, turning to respectability). Chang observed that the most important step in a woman's life was "going upstairs" either to become 花瓶 (huaping, a vase symbolizing a woman's identity as concubine) or become 太太 (taitai, legal spouse) ("Zou" 97-100). But what happened after a courtesan realized the elevation of her social status and relocated from the courtesan house to the respectable inner boudoir? In the novel, the story of Huizhen Zhang speaks to the dilemma of domestication and the limitations regarding the woman's position and space. In the triangular relationship between Liansheng Wang, Xiaohong Shen, and Huizhen Zhang, Huizhen is the one who receives little attention because of her weak character. Taking advantage of Liansheng's retaliation against Xiaohong-one of the top-ranking courtesans who maintains a stable relationship with Liansheng for five years and secretly pursues a liaison with Liu'er Xiao, an opera singer-Huizhen wins over Liansheng and turns from 么二 (yao'er, courtesan of lower rank) into a top-ranking courtesan. Eventually, Huizhen replaces Xiaohong, the concubine-to-be for Liansheng, and marries him as his concubine. Going upstairs along the social ladder from the courtesan house to the inner chamber of the Wang mansion, home of an officer of foreign affairs sojourning in the Shanghai concessions, Huizhen seems to achieve a happy ending. Ironically, soon after the marriage, Huizhen is beaten and thrown out of the family by Liansheng because she is caught committing adultery with Liansheng's nephew. Leaving the pseudo-domestic space of the courtesan house, Huizhen has to lead a different 
Xiaojue Wang, "Han's (韓邦慶) Novel 海上花列傳 (The Sing-Song Girls of Shanghai) and Urbanity in Late Qing Shanghai" page 6 of 8 CLCWeb: Comparative Literature and Culture 17.1 (2015): <http://docs.lib.purdue.edu/clcweb/vol17/iss1/9>

Thematic Issue The Study of Chinese Literature in the Anglophone World. Ed. Shunqing Cao

life within the familial order bound by Confucian norms. Whereas the entrance into the family sphere increases the social status of the courtesan, it also demands her subjection to the authority of the traditional family system. Huizhen is punished for her committing adultery in chapters 9 and 54 respectively. In chapter 9 she is beaten up by Xiaohong in Zhang Yuan after the latter finds out that Liansheng has started a new relationship with Huizhen. Huizhen's fault lies in her violation of the "family ethic" sham in the courtesan house, a make-believe domestic space. In chapter 54, after she marries Liansheng as his concubine, her affair with his nephew is exposed. This time she transgresses the family scruples in a real domestic sphere and the penalty she receives is far beyond physical: she eventually loses her newly earned respectable familial and social position. As Huizhen's experiences reveal, the imitation of domesticity within the courtesan house only stresses the unbridgeable gap separating it from a conventional familial space.

Cuifeng Huang's story provides another interesting case of how the distinction between the courtesan house and the orthodox domestic sphere might be reinforced by the courtesan herself. With her shrewdness and ability, Cuifeng is one of the most impressive characters in the novel. She is too sober to be deceived by the spectacular social façade of courtesan life, the family charade within the courtesan house, or a respectable family life in the traditional social order. Capitalizing on her relationships with Zifu Luo and Zigang Qian, the two clients with whom she maintains a stable relation simultaneously, Cuifeng eventually succeeds in buying herself out of the courtesan house and opening her own courtesan business. Further, Cuifeng's refusal to enter the domestic space echoes Xiaxian Wei's remarks quoted at the beginning of my study and emphasizes the demarcation between the scholargentry family and the courtesan house as a competitive, independent space. However, it would be too hasty to conclude that Cuifeng's choice to remain in the courtesan house as an owner instead of marrying a client suggests a self-conscious resistance against the traditional family. Although the novel provides little information about Cuifeng's life after running her own business, it describes Mingzhu Tu as Cuifeng's elderly alter ego. Mingzhu, once a popular courtesan, runs her own brothel and becomes the 老铇 (laobao, the madame who owns the business). When she gets old and is again called on to entertain a client, she becomes the laughingstock of the town. Although she is financially secure and independent, she has by no means obtained respectable social status.

Beginning from chapter 38, the novel shifts its focus from the urban courtesan life to the description of a classical literati life in Yili Yuan, which makes up the bulk of the second half of Sing-Song Girls. Several scholars criticized the Yili Yuan part as a flaw of the novel (e.g., Lu Xun; Hu; Liu) and Liu, for instance, contends that as a result of the Yili Yuan part "the charm of the novel transforms to monotony, transforms to dullness" (601). If one follows Peter Brooks's argument that "plot is the logic and dynamic of narrative, and narrative itself a form of understanding and explanation" (10), how should one cope with the apparent structural and thematic inconsistency of the novel? I argue that the particular narrative discrepancy not only bespeaks the late Qing intellectuals' response to the controversial sociocultural values in the transitional era of the last fin-de-siècle, but also reveals the ambivalence intrinsic in May Fourth notion of modernity. Liu is right in pointing out the discordance between the two parts of the novel with chapter 38 serving as a watershed. The main distinctions between the Yili Yuan part and the first half of the novel reside in the competition between traditional literati cultural values and a modern secular lifestyle rising in the Shanghai concessions over the last decades of the nineteenth century. The conspicuous difference between the two parts is the shift in the physical location of the plot accompanied by disparate cultural and social activities. The first part of the novel is set in the prosperous commercial district of the Shanghai concessions marked by a modern Western culture and lifestyle, with Zhang Yuan, the park, serving as its epitome. The second part is moved to the fictional Yili Yuan, a walled private garden owned by Yunsou Qi, who belongs to the traditional scholar-gentry class.

It is noteworthy that Yili Yuan is sheer fabrication, although the places in the first part are depicted in a realistic manner and their locations can be charted physically in a late Qing map of Shanghai. Readers would hardly miss the similarities between Yili Yuan in The Sing-Song Girls and 大觀園 (Daguan Yuan, Grand View Garden) in the Dream of the Red Chamber, the Qing dynasty classic about the lives of four prestigious families. Evidently, Han uses Daguan Yuan as his primary model to fashion an ideal classical Chinese garden and the similarities rest in not only buildings and garden landscapes, but also characters and themes. What distinguishes the Yili Yuan part from the first part of the novel is 
Xiaojue Wang, "Han's (韓邦慶) Novel 海上花列傳 (The Sing-Song Girls of Shanghai) and Urbanity in Late Qing Shanghai" page 7 of 8 CLCWeb: Comparative Literature and Culture 17.1 (2015): <http://docs.lib.purdue.edu/clcweb/vol17/iss1/9>

Thematic Issue The Study of Chinese Literature in the Anglophone World. Ed. Shunqing Cao

also a shift in the constitution of the clients. Whereas the male customers gathering in Yili Yuan are mostly traditional literati, customers in the first part are merchants and clerks. With the change in clientele, daily routines and activities also change. In a courtesan house, the simple, vulgar fingerguessing game 划拳 (huaquan), is popular. In Yili Yuan, however, what is done is traditional scholarly drinking games, which demand good knowledge of and quotations from Confucian classics and classical poetry. When the merchant Xiaoyun Chen is invited to a party in Yili Yuan, he is worried that he will have to compose traditional poems in a literati banquet (chapter 48). Han places equal significance on these two parts in terms of narrative space and plot arrangement. The defining episode of the novel-namely the composition of the profiles of the top-ranking courtesans in Shanghai, from which the novel's title comes-takes place inside Yili Yuan. Although pivotal, the Yili Yuan part seems archaic and out of place for May Fourth critics. For example, to account for the narrative fault, Liu argues that Han, a frustrated scholar who failed the civil service examination, intends to fill in the novel with his own works of classical Chinese prose and poems. However, such an effort to show off classical learning is bound to fail in the un-Chinese foreign concessions and Chang observes that through the Yili Yuan part, Han attempts to prove that he is not merely an author of the pleasure quarter, but is equally as good at portraying refined, elite cultural life as his predecessor in the Dream of the Red Chamber ("Remembering" 153).

As May Fourth critics dismiss the antiquated literati world in the novel, they fail to notice that the narrative controversy is a necessary consequence of Han's efforts to reshuffle conflicting cultural and ethical values in late Qing Shanghai, a transitional moment when the old and the new confronted, competed with, and contested the modern. The juxtaposition of the Yili Yuan and the concessions parts demonstrates Han's ambivalent attitude toward tradition and modern ideas. Whereas he appreciates the new Western-style life, he nevertheless feels nostalgic towards literati life in a classical world. The novel's narrative and thematic inconsistency is therefore symptomatic of an era of rite de passage in late Qing Shanghai.

In conclusion, the novel's Zhang Yuan part represents a form of commercial, Westernized mass culture for a newly arising urban middle class, which threatens the obsolete, elite literati culture epitomized by Yili Yuan. Although courtesans are brought across the boundary between these two worlds and enter the elite space, they will never mutate into scholarly courtesans of the late Ming style. Whereas Han shows nostalgia for a classical, elite scholar style, May Fourth intellectuals discarded the traditional as archaic and favor the quotidian, modern world. By rejecting the classical Yili Yuan part, May Fourth criticism betrayed its dominant cultural agenda as "totalistic antitraditionalism," which envisions a modernity as a complete break with the tradition and with the past (see Lin). In Sing-Song Girls, however, it is the contestation and negotiation between the traditional and emergent modernist cultural values which entail the inconsistency in its narrative structure. These moments of hesitation and ambivalence in Sing-Song Girls when the old and the new are competing and contesting the modern attribute a distinctive quality to the novel.

\section{Works Cited}

Benjamin, Walter. "Charles Baudelaire. Ein Lyriker im Zeitalter des Hochkapitalismus." Gesammelte Schriften. By Walter Benjamin. Ed. Rolf Tiedemann and Hermann Schweppenhäuser. Frankfurt: Suhrkamp, 1991. Vol. 1, 511-604.

Brooks, Peter. Reading for the Plot: Design and Intention in Narrative. New York: Vintage, 1985.

Carlitz, Katherine. "Desire and Writing in the Late Ming Play Parrot Island." Writing Women in Late Imperial China. Ed. Ellen Widmer and Kang-i Sun. Stanford: Stanford UP, 1997. 101-30.

Chang, Eileen (張愛玲). "走, 走到樓上去" ("Go, Go Upstairs"). 流言(Written on Water). By Eileen Chang. Taipei: Huangguan chubanshe, 1991. 97-100.

Chang, Eileen 張愛玲). "國語本海上花譯後記" (Postscript to the Mandarin Translation of The Sing-Song Girls). 海上花開 一海上花落 (Flowers Bloom, Flowers Fade). By Eileen Chang. Taipei: Huangguan chubanshe, 1981. 631-48.

Chang, Eileen (張愛玲). "憶胡適之" (Remembering Shi Hu). 張看 (Chang's View). By Eileen Chang. Taipei: Huangguan chubanshe, 1976. 141-54.

Han, Bangqing (韓邦慶). 海上花列傳 (The Sing-Song Girls of Shanghai). Taipei: Guangya chubanshe, 1984.

Han, Bangqing. The Sing-Song Girls of Shanghai. Trans. Eileen Chang. New York: Columbia UP, 2005.

Henriot, Christian. Belles de Shanghai. Prostitution et sexualité en Chine aux XIXe-XXe siècles. Paris: CNRS, 1997.

Hershatter, Gail. Dangerous Pleasures: Prostitution and Modernity in Twentieth-Century Shanghai. Berkeley: U of California P, 1997.

Hu, Shi (胡適). "海上花列傳序" ("Preface to The Sing-Song Girls"). 海上花列傳. Taipei: Guangya chubanshe, 1984. 122. 
Xiaojue Wang, "Han's (韓邦慶) Novel 海上花列傳 (The Sing-Song Girls of Shanghai) and Urbanity in Late Qing Shanghai" page 8 of 8 CLCWeb: Comparative Literature and Culture 17.1 (2015): <http://docs.lib.purdue.edu/clcweb/vol17/iss1/9>

Thematic Issue The Study of Chinese Literature in the Anglophone World. Ed. Shunqing Cao

Ko, Dorothy. Teachers of the Inner Chambers: Women and Culture in Seventeenth-century China. Stanford: Stanford UP, 1994.

Li, Boyuan (李伯元). 文明小史 (Modern Times). Taipei: Shijie shuju, 1974.

$\mathrm{Li}$, Wai-yee. "The Late Ming Courtesan: Invention of a Cultural Ideal." Writing Women in Late Imperial China. Ed. Ellen Widmer and Kang-i Sun. Stanford: Stanford UP, 1997. 46-73.

Liang, Qichao (梁啓超). 新中國未夾記 (The Future of New China). Taipei: Guangya chubanshe, 1984.

Lin, Shu (林紟) and Wang Shouchang (王壽昌). 巴黎茶花女遺事 (The Story of La Dame aux Camélias of Paris). Fuzhou: Weilu, 1899.

Lin, Yusheng. The Crisis of Chinese Consciousness: Radical Antitraditionalism in the May Fourth Era. Madison: $U$ of Wisconsin P, 1979.

Liu，Fu (劉復). 讀海上花列傳 (Reading The Sing-Song Girls). 海上花列傳. Taipei: Heluo chubanshe, 1980.

Lu，Xun (魯迅). 中國小說史略 (Brief History of Chinese Fiction). 魯迅全集 (Complete Works of Lu Xun). By Lu Xun. Beijing: Renmin wenxue chubanshe, 1981. Vol. 9.

Ma, Bohuang (馬伯煌)，ed. 上海近代經濟開發思想史 (An Economic History of Modern Shanghai). Kunming: Yunnan renmin chubanshe, 1991.

Mann, Susan. Precious Records: Women in China's Long Eighteenth Century. Stanford: Stanford UP, 1997.

McMahon, Keith. "Fleecing the Male Customer in Shanghai Brothels of the 1890s." Late Imperial China 23.2 (2002): 1-32.

Wakeman, Jr. Frederic, and Wen-hsin Yeh. Shanghai Sojourners. Berkeley: U of California P, 1992.

Wang, David Der-wei. Fin-de-siècle Splendor: Repressed Modernities of Late Qing Fiction, 1849-1911. Stanford: Stanford UP, 1997.

Xue, Liyong (薛理勇). 上海妓女史 (A History of Prostitution in Shanghai). Hong Kong: Haifeng chubanshe, 1996.

Yeh, Catherine Vance. "Reinventing Ritual: Late Qing Handbooks for Proper Customer Behavior in Shanghai Courtesan Houses." Late Imperial China 19.2 (1998): 1-63.

Yeh, Catherine Vance. Shanghai Love: Courtesans, Intellectuals, and Entertainment Culture, 1850-1910. Seattle: U of Washington $\mathrm{P}, 2006$.

Yuan, Jin (袁進)，and Chen Bohai (陳伯海)，eds. 上海近代文學史 (Modern Literary History of Shanghai). Shanghai: Shanghai renmin chubanshe, 1993.

Zamperini, Paola. "But I Never Learned to Waltz: The 'Real' and Imagined Education of a Courtesan in the Late Qing." Nan Nü 1.1 (1999): 107-44.

Zhang, Yingjin. The City in Modern Chinese Literature and Film: Configurations of Space, Time, and Gender. Stanford: Stanford UP, 1996.

Author's profile: Xiaojue Wang teaches modern Chinese literature and film at the University of Pennsylvania. Her interests in scholarship include modern Chinese literature, critical theory and cultural studies, gender and sexuality, film and visual studies, and comparative literature, and in particular literary relations between Germany and China. In addition to numerous articles, Wang is author of Modernity with a Cold War Face: Reimagining the Nation in Chinese Literature across the 1949 Divide (2013). E-mail: <xiaojuew@sas.upenn.edu> 